\title{
Epidemiology and impact of hallux valgus: more than just bunions
}

\author{
Edward Roddy \\ From Australasian Podiatry Council Conference 2011 \\ Melbourne, Australia. 26-29 April 2011
}

Hallux valgus (HV) is a common deformity characterized by progressive lateral deviation of the great toe at the first metatarsophalangeal joint ( $1^{\text {st }}$ MTPJ). It commonly associates with a painful overlying soft-tissue prominence, the "bunion". A recent systematic review estimated the prevalence of HV to be $23 \%$ in adults aged 18 to 65 years. It becomes more frequent with increasing age and is more prevalent in women than men. Several potential risk factors for $\mathrm{HV}$ have been identified. Various mechanical factors are thought to associate with HV including metatarsal length and headshape, first ray hypermobility and foot posture. $\mathrm{HV}$ is rare in unshod populations but associates with wearing high-heeled or narrow shoes. The relationship between $\mathrm{HV}$ and obesity is less clear. Some studies have found an association between $\mathrm{HV}$ and increasing body mass index (BMI) whereas others have found no association. Most recently, it has been suggested that the association between HV and BMI differs between the genders, with a lower prevalence with increasing BMI in women but no association in men.

HV poses a significant health problem, and associates with foot pain, poor balance, gait impairment, immobility, and risk of falling. The likelihood of $1^{\text {st }}$ MTPJ osteoarthritis (OA) increases with HV severity but nodal $\mathrm{OA}$ and pain at the low back, hip and knee are also associated with $\mathrm{HV}$, suggesting that it is a component of generalised OA. Several recent studies have examined the relationship between $\mathrm{HV}$ and health-related quality of life (HRQOL). Symptomatic HV appears to associate with reduced HRQOL. However, both general and footspecific HRQOL are progressively lower with increasing severity of HV deformity, regardless of foot pain. Importantly, the association of both the presence and severity

Correspondence: e.roddy@cphc.keele.ac.uk

Arthritis Research UK Primary Care Centre, Keele University, Staffordshire, ST5 $5 B G$, UK

of HV with impaired HRQOL is not limited to pain and physical function but extends to general health, vitality, social function, and mental health. In summary, the impact of HV extends beyond local influence on foot OA, balance, gait and falls, to impair HRQOL. Future prospective studies are required to identify risk factors for the development and progression of $\mathrm{HV}$ and hence possible targets for prevention and intervention.

Published: 20 May 2011

doi:10.1186/1757-1146-4-S1-A8

Cite this article as: Roddy: Epidemiology and impact of hallux valgus: more than just bunions. Journal of Foot and Ankle Research 2011 4(Suppl 1):A8.

Submit your next manuscript to BioMed Central and take full advantage of:

- Convenient online submission

- Thorough peer review

- No space constraints or color figure charges

- Immediate publication on acceptance

- Inclusion in PubMed, CAS, Scopus and Google Scholar

- Research which is freely available for redistribution 